\title{
Tartós immunonephrológiai gondozásban részesült lupus nephritises betegeink hosszú távú kezelési eredményei
}

\author{
Polner Kálmán dr. ${ }^{1}$ - Arányi József dr. $^{2}$ - Braunitzer Henrik dr. ${ }^{2}$ \\ Kaszás Ilona dr. ${ }^{3}$ - Haris Ágnes dr. ${ }^{4}$ \\ ${ }^{1}$ Szent Margit Kórház, Taraba István Múvese Állomás, Budapest \\ ${ }^{2}$ Szent Margit Kórház, II. Belgyógyászat, Nephrológia és Gasztroenterológia Osztály, Budapest \\ ${ }^{3}$ Szent Margit Kórház, Patológia Osztály, Budapest \\ ${ }^{4}$ Péterfy Kórház-Rendelőintézet és Manninger Jenő Országos Traumatológiai Intézet, \\ I. Belgyógyászat, Nephrológia és Gasztroenterológia Osztály, Budapest
}

\begin{abstract}
Bevezetés: A systemás lupus erythematosus (SLE) legsúlyosabb manifesztációja a lupus nephritis, melynek kialakulása és az immunszuppresszív kezelés eredményessége alapvetően meghatározza a betegek életkilátását és életminőségét. Célkitüzés: Retrospektív obszervációs vizsgálatunk célja a Szent Margit Kórház Immunonephrologiai Ambulanciáján lupus nephritis miatt tartósan gondozott betegeink hosszú távú kezelésének értékelése volt.

Eredmények: Vizsgálatunkban az 1997. december 1. és 2019. április 30. között gondozott lupus nephritises betegek adatait elemeztük. A 73 betegnél (akik 33,7 15 évesek, 82\% nő, 18\% férfi, a megfigyelési idő középértéke 119 hó [szélsőértékek 3-264]) a lupus nephritis diagnosztizálásakor a betegek nagy részében jelentősen beszúkült vesefunkciót észleltünk, az eGFR 68 [7-120] ml/min, a proteinuria 2800 [23-16812] mg/nap volt; 10 fó akutan hemodialízis-kezelésre szorult. A 68 foonél elvégzett vesebiopszia eredménye 55 foonél proliferatív, 6 betegnél membranosus lupus nephritist igazolt. Kombinált immunszuppresszió alkalmazásával 50 esetben komplett, 21 betegnél részleges remissziót sikerült elérni; 28 főnél egy vagy több alkalommal relapsus jelentkezett. Ketten már a gondozásba kerülésükkor krónikus dialízisre szorultak, emellett 3 betegnél a vesefunkció hosszú távon végstádiumú veseelégtelenségig progrediált. A többiek vesemúködése stabilizálódott, közel normálissá váltak a SLE aktivitását jelző SLEDAI-pontszám, a komplement- és immunleletek.

Következtetések: A lupus nephritis kombinált indukciós és elhúzódóan alkalmazott fenntartó immunszuppresszióval megfelelően kezelhető, a betegség progressziójának megakadályozásához azonban tartós gondozás szükséges, nephrologus-immunológus együttmúködésével. Az alapbetegség többszervi manifesztációjának és az immunszuppresszió potenciális szövődményeinek kivédésére az ellátó teamnek magában kell foglalnia mindazon szakembereket, akik hozzájárulhatnak a komplex ellátást igénylő betegek állapotának javulásához. Célszerű, hogy a lupus nephritises beteg gondozását és az együttmúködő team vezetését nephrologus irányítsa.

Orv Hetil. 2020; 161(31): 1293-1301.
\end{abstract}

Kulcsszavak: systemás lupus erythematosus, lupus nephritis, glomerulonephritis, nephrosis syndroma, immunszuppresszió

\section{Outcome of patients with lupus nephritis under long-term immunonephrological care}

Introduction: Lupus nephritis is the most severe complication of systemic lupus erythematosus (SLE), its development and the effectiveness of immunosuppressive therapy substantially influence patients' quality of life and survival. Aim: In this retrospective observational investigation, the long term-outcome of patients with lupus nephritis, followed at the St. Margit Hospital Immunonephrological Outpatient Clinic, was evaluated.

Results: Between 1997 December 1 and 2019 April 30, 73 patients (age $33.7 \pm 15$ years, 82\% female, 18\% male) were under care with median observation of 119 [between 3-264] months. At diagnosis, eGFR showed 68 [7-120] $\mathrm{ml} / \mathrm{min}$, proteinuria was 2800 [23-16812] mg/day; 10 patients needed dialysis treatment acutely. Renal biopsy, 
performed in 68 patients, proved proliferative lupus nephritis in 55 and pure membranous lupus nephritis in 6 patients. Administering combined immunosuppressive therapy, complete remission was achieved in 50 and partial remission in 21 cases; one or repeated relapses developed in 28 subjects. Two patients, by the time they got under our care, had already required chronic dialysis, and in the long term, three more patients progressed to end-stage renal disease requiring renal replacement therapy. Renal function stabilized in all other participants, clinical activity of SLE, SLEDAI score, complement levels and immunserology results improved significantly.

Conclusions: Lupus nephritis can be effectively treated by combined induction and prolonged maintenance immunosuppression, but to prevent progression of the disease, long-term care is necessary by co-operation of nephrologist and immunologist. To provide adequate prevention and therapy of the SLE's multiorgan involvement and also the potential complications of immunosuppression, multidisciplinary team is needed with all specialists who may facilitate these patients' complex care. For the long-term management of patients with lupus nephritis, the nephrologists have to be responsible, and the multidisciplinary teams also have to be under their direction.

Keywords: systemic lupus erythematosus, lupus nephritis, glomerulonephritis, nephrotic syndrome, immunosuppression

Polner K, Arányi J, Braunitzer H, Kaszás I, Haris Á. [Outcome of patients with lupus nephritis under long-term immunonephrological care]. Orv Hetil. 2020; 161(31): 1293-1301.

(Beérkezett: 2020. március 24.; elfogadva: 2020. április 16.)

\section{Rövidítések}

ANCA = antineutrophil citoplazmikus antitest; anti-dsDNS = (anti-double stranded DNA antibody) kettős szálú DNS elleni antitest; DNS = dezoxiribonukleinsav; eGFR = (estimated glomerular filtration rate) becsült glomerulusfiltrációs ráta; EULAR $=($ European League Against Rheumatism $)$ Európai Reumaellenes Liga; GFR = (glomerular filtration rate) glomerulusfiltrációs ráta; $\mathrm{HD}=$ hemodialízis; $\mathrm{Hgb}=$ hemoglobin; ISN $/$ RPS $=($ International Society of Nephrology/Renal Pathology Society) Nemzetközi Nephrologiai Társaság/Vesepatológiai Társaság; ISU = immunszuppresszív; LN = lupus nephritis; NEAK = Nemzeti Egészségbiztosítási Alapkezelő (az OEP jogutódja); OGYÉI = Országos Gyógyszerészeti és Élelmezés-egészségügyi Intézet; SLE = (systemic lupus erythematosus) szisztémás lupus erythematosus; SLEDAI $=$ (systemic lupus erythematosus disease activity index) a szisztémás lupus erythematosus betegség aktivitási indexe; WHO = (World Health Organization) Egészségügyi Világszervezet

A systemás lupus erythematosus (SLE) leggyakrabban fiatal nőket érintő, sokszervi manifesztációval járó autoimmun betegség [1]. Veseérintettség a betegek $50-75 \%$ ában kialakul, a legtöbbször a SLE diagnózisának felállítását követő hónapokban-években manifesztálódik, de előfordul, hogy a beteg még meg nem állapított, egyéb klinikai jelekkel alig rendelkező SLE-vel és már kialakult vesekárosodás tüneteivel keresi fel orvosát. Néhány évtizede, hatékony terápiás lehetôségek nélkül, a SLE egyik legveszélyesebb szervi manifesztációjaként jelentkező súlyos nephrosis vagy progrediáló veseelégtelenség nemegyszer a betegség halálos szövődményét jelentette.

A lupus nephritis (LN) klinikumára glomerulonephritis vagy nephrosis képe jellemző $[2,3]$. Típusos a proteinuria megjelenése, amelyet gyakran microhaematuria kísér. A korai szakban a GFR legtöbbször a normális tar- tományon belüli, későn diagnosztizált vagy nem megfelelően kezelt esetekben azonban a GFR fokozatosan vagy rapidan csökken, akár súlyos vesekárosodás, végstádiumú veseelégtelenség is kialakulhat. A betegségre jellemző, hogy az immunszuppresszív (ISU-) terápiával elért remissziót magas arányban, irodalmi adatok alapján 25-50\%-ban ismétlődő relapsusok komplikálják $[3,4]$. Relapsusok kapcsán tovább károsodhat a vesemúködés, növekszik a veseelégtelenség rizikója. Végstádiumú veseelégtelenség kialakulásával napjainkban is számolni kell, ez a betegek mintegy $10 \%$-ában következik be $[4,5]$.

A betegség kimenetelét a megfelelően megválasztott ISU-terápia alapvetôen meghatározza [6-8]. Az immunszuppresszió alapját a kortikoszteroid képezi, amelyet proliferatív LN-ben és nephrosissal járó membranosus LN-ben kombinációban kell alkalmazni. Klasszikus szerünk, a ciklofoszfamid mellett újabb gyógyszerek is rendelkezésünkre állnak, mint a mikofenolát, a ciklosporin és a rituximab. Bár ezek birtokában a kimenetelt az elmúlt években nagyban javítani lehetett, napjainkban is találkozunk terápiarezisztens esetekkel [9]. Vizsgálatunk célja kombinált ISU-terápiás protokollunk és tartós gondozásunk hatékonyságának áttekintése, betegeink hoszszú távú kezelésének értékelése volt. Nephrologiai központunk 21 éves tapasztalatainak összefoglalásával arra kívánjuk felhívni a figyelmet, hogy a LN megjelenése és kimenetele milyen jelentős mértékben változtatja meg a betegek életminőségét és további sorsát.

\section{Módszer}

Retrospektív megfigyeléses vizsgálatunkban a Szent Margit Kórház Immunonephrologiai Ambulanciáján 1997. december 1. és 2019. április 30. között gondozott LN-betegek adatait elemeztük. 
A vizsgálatba minden olyan, 18-80 év közötti, rendszeresen gondozott krónikus LN-beteget bevontunk, aki hozzájárult az adatgyüjtéshez és az eredmények anonim módon történő publikálásához. A demográfiai adatok és a vesebiopsziás eredmények mellett meghatároztuk a betegeknek a gondozásunkba kerülésükkor és a megfigyelési időszak végén dokumentált rutin laboratóriumi leleteit, a proteinuria mértékét és az immunológiai eredményeket (a komplementek, az antinukleáris antitestek, az antikardiolipin-antitestek és az ANCA szintjeit). Kiszámítottuk a betegség szisztémás aktivitását jelző SLEDAI-pontszámot (a pontszám SLE okozta, újonnan kialakult, központi idegrendszeri eredetű neurológiai tünetek, pszichózis, heveny retinalis exsudatio, vérzés, opticus neuritis vagy vasculitis esetén 8-8 pont, arthritis, myositis, akut vesekárosodásra utaló vizeletleletek esetén 4-4 pont, bőrkiütés, alopecia, nyálkahártyafekélyek, pleuritis, pericarditis, alacsony komplement- vagy magas anti-dsDNS-értékek esetén 2-2 pont, láz, thrombocytopenia, leukopenia kialakulásakor 1-1 pont összeadásával számítható ki). Összegeztük az alkalmazott indukciós és fenntartó ISU-terápiát, meghatároztuk a részleges és komplett remisszió, illetve a relapsusok gyakoriságát, a dialízisszükségletet, az exitus bekövetkeztét és okát, valamint a súlyos szövődmények előfordulását. Súlyos infekción a kórházi ellátást igénylő fertőzéseket értettük. Vizsgáltuk a iatrogén leukopenia, a súlyos osteoporosis, a szteroiddiabetes és a thrombosisok gyakoriságát. A veseszövettani értékelést vesepatológusaink a korai években a WHO-klasszifikáció alapján, 2004-et követően az ISN/RPS 2003. évi osztályozása alapján [10] végezték (1. táblázat).

Komplett remissziót akkor állapítottunk meg, ha a szérumkreatinin-szint mérséklődött vagy stabilizálódott, a vizeletüledékben nem volt aktivitásra utaló microhaematuria vagy cylindruria, és a proteinuria napi $500 \mathrm{mg}$ alá csökkent. Részleges remissziót stabil szérumkreatinin és inaktív vizeletüledék, de 500 mg-ot meghaladó proteinuria esetén diagnosztizáltunk [4].

1. táblázat | A lupus nephritis ISN/RPS szerinti 2003. évi osztályozásának rövid összefoglalása

\begin{tabular}{ll}
\hline I. csoport & Minimális mesangialis lupus nephritis \\
\hline II. csoport & Mesangialis proliferatív lupus nephritis \\
\hline III. csoport & Fokális lupus nephritis \\
\hline IV. csoport & Diffúz szegmentális vagy globális lupus nephritis \\
\hline V. csoport & Membranosus lupus nephritis* \\
\hline VI. csoport & Előrehaladott szklerotizáló lupus nephritis \\
\hline
\end{tabular}

*Kombinált membranosus és proliferatív jelekkel bíró glomerularis elváltozások esetén mindkettőt diagnosztizálni kell (V. + III. vagy V. + IV.)

ISN/RPS = Nemzetközi Nephrologiai Társaság/Vesepatológiai Társaság
Betegeinket a LN aktív szakaszában 2-4 hetente, a fenntartó immunszuppresszió során az állapotuktól, vesefunkciójuktól függően 1-3 havonta, tartós remisszió esetén félévente ellenőriztük.

A kutatást a Szent Margit Kórház Intézeti Kutatásetikai Bizottságának engedélyével végeztük. A statisztikai analízis a SPSS 25.0 statisztikai szoftvercsomag (IBM, Armonk, NY, Amerikai Egyesült Államok) alkalmazásával készült, az eredményeket normáleloszlás esetén az átlag \pm szórás, egyéb esetekben a közép- és szélsőértékek megadásával dokumentáltuk.

\section{Eredmények}

Immunonephrologiai szakambulanciánkon 1997 és 2019 között LN miatt 73 beteg részesült tartós gondozásban, a megfigyelési időszak középértéke 119 [szélsőértékek 3-264] hónap volt. A 60 nő és 13 férfi esetében a SLE 30,4 \pm 14 éves korban jelentkezett, a LN átlagosan 3,3 évvel később került felismerésre. A betegeknek a gondozásunkba kerülésükkor dokumentált demográfiai és klinikai adatait a 2. táblázat tartalmazza. A SLEDAIpontszám igen magas értéke magas betegségaktivitást, sokszervi érintettséget igazolt. A LN proteinuria, haematuria, több esetben vesefunkció-romlás alapján felállított diagnózisát a vesebiopszia szövettani vizsgálatával erősítettük meg. A biopsziát csak 5 betegnél mellőztük, ennek indoka 1 betegnél szoliter vese volt; 3 esetben, a betegek kérését is figyelembe véve, az enyhe $(500 \mathrm{mg} /$ nap alatti) proteinuria, az aktív vizeletüledék hiánya és a normális GFR alapján kombinált immunszuppressziót nem igénylő enyhe LN-t (I. vagy enyhe II. osztály) véleményeztünk. Egy beteg évekkel korábban, már a diagnózis felállításakor végstádiumú veseelégtelen volt és dialízisre szorult, késóbb vesetranszplantáción esett át, majd 10 év múlva vesefunkció-romlás miatt ismét dialízisprogramba került. Ezt követően a dialízis melletti relapsus

2. táblázat | Betegeink demográfiai adatai és vesekárosodásuk

\begin{tabular}{lc}
\hline Életkor a SLE megállapításakor (év) & $30,4 \pm 14$ \\
\hline Életkor a LN megállapításakor (év) & $33,7 \pm 15$ \\
\hline Nemi megoszlás & 60 nő/13 férfi \\
\hline Gondozásunk időtartama (hónapok) & $119(3-264)$ \\
\hline A LN szövettani osztályai, 68 fő (az egyes & II. osztály: 7 \\
osztályokba tartozó betegek száma) & III. osztály: 11 \\
& IV. osztály: 43 \\
& V. + III. osztály: 1 \\
& V. osztály: 6 \\
\hline
\end{tabular}

Glomerularis félhold képződésével járó 21

szövettani forma (betegek száma)

Az akut HD-t igénylő betegek száma a LN

diagnózisának felállításakor 10

HD = hemodialízis; LN = lupus nephritis; SLE = szisztémás lupus erythematosus 
kapcsán került gondozásunkba, ekkor a beavatkozás magas rizikója miatt mellőztük a biopsziát.

A szövettani eredmény alapján 11 beteg a III., 43 a IV., l pedig az V. + III. osztályba tartozott, azaz proliferatív LN 55 esetben volt igazolható. Hat betegnél találtunk tisztán membranosus LN-t (V. osztály), 7-en tartoztak a LN II. szövettani csoportba. A vesefunkció és a klinikai eredmények alakulását - a szakirodalmi ajánlásokat követve - 'proliferatív LN', illetve 'membranosus LN' csoportosításban értékeljük [2].

A 'proliferatív LN' csoportban a vesefunkció a gondozásunk kezdetén jelentősen beszúkült, a szérumkreatinin átlaga $172 \mu \mathrm{mol} / \mathrm{l}$, az eGFR $60 \mathrm{ml} / \mathrm{min}$ volt (közép- és szélsőértékek: kreatinin 127 [49-636] mol/1, eGFR 55 [7-120] $\mathrm{ml} / \mathrm{min})$. Minden betegnél kimutatható volt microhaematuria és proteinuria, ez utóbbi mennyisége 3237 [260-16812] mg/nap. A vizeletfehérje-kiválasztás a betegek 33\%-ában nephroticus mértéket ért el. A csoport szérumalbumin-átlaga $29 \pm 7 \mathrm{~g} / 1$, a Hgb 10,9 \pm 2 $\mathrm{g} \%$, a C3-as komplement $0,61 \pm 0,3 \mathrm{~g} / 1$ volt, és az antidsDNS értéke jelentósen meghaladta a normáltartomány felső határát $(33$ [2-100] U/ml). Akut glomerulonephritis zajlását jelezte a vérnyomás magas értéke is (3. táblázat). A vesebiopszia szövettani értékelése a proliferatív LN-t jellemző hisztológiai eltérések között 21 betegben a legsúlyosabb, glomerularis félholdas elváltozásokat is igazolt. A diagnózis időpontjában 10 betegnél olyan súlyos, heveny vesefunkció-romlást észleltünk, hogy akutan hemodialízis (HD)-kezelést kellett végezni, amely a későbbiekben az ISU-terápia mellett javuló vesefunkciók alapján elhagyhatóvá vált. (További 2 beteg már hoszszabb ideje fennálló, végstádiumú veseelégtelenséggel került hozzánk, ők a továbbiakban is vesepótló kezelésre szorultak.)

Tisztán membranosus, proliferatív jelek nélküli LN 6 betegnél volt kimutatható. Ebben az alcsoportban az igen jelentős proteinuria (4337 [1145-9787] mg/nap) és hypalbuminaemia $(28 \pm 9 \mathrm{~g} / \mathrm{l})$ dominált, a szérumkreatinin (átlag 102, közép- és szélsőértékek 69 [61249] $\mu \mathrm{mol} / 1$ ) és az eGFR (átlag 88, közép- és szélsőértékek 95 [23-120] ml/min) kevésbé tért el a normálistól, mint azt a proliferatív LN alcsoportjának betegeinél tapasztaltuk. Enyhébbnek bizonyult az anaemia, a hypertonia, a C3-as komplement csökkenése és az anti-dsDNS emelkedése is (3. táblázat).

Az ISN/RPS 2003. évi LN-osztályozása alapján a II. csoportba 7 beteget soroltunk. Bár a szövettani elváltozás kevésbé súlyos képet jelzett, a csoport 2 betegénél jelentősen (eGFR 35 és $39 \mathrm{ml} / \mathrm{min}$ ), két esetben mérsékelten beszűkült vesefunkciót (eGFR 64 és $67 \mathrm{ml} / \mathrm{min}$ ) találtunk. A magas SLEDAI-pontszám (17,9 \pm 7 ) jelentős szisztémás betegségaktivitást igazolt. Szövettani vizsgálattal I. vagy VI. osztályú LN-betegünk nem volt.

$\mathrm{Az}$ indukciós ISU-kezelés minden betegnél tartalmazott kortikoszteroidot, amelyet súlyos klinikai kép esetén, a betegek 73\%-ában, 3 egymást követő napon, napi 500-1000 mg intravénás bolusban (átlag $598 \pm 241 \mathrm{mg}$ )
3. táblázat Laboratóriumi és klinikai adatok a betegek gondozásunkba ke rülésekor, a szövettani eredmények alapján csoportosítva

\begin{tabular}{|c|c|c|c|c|}
\hline & $\begin{array}{l}\text { Összes } \\
\text { beteg }^{\star} \\
(\mathrm{n}=73)\end{array}$ & $\begin{array}{l}\text { LN II. } \\
(\mathrm{n}=7)\end{array}$ & $\begin{array}{c}\text { Proliferatív } \\
\text { LN } \\
\text { (III. + IV. + } \\
\text { V. + III. }) \\
(\mathrm{n}=55)\end{array}$ & $\begin{array}{l}\text { Membrano- } \\
\text { sus LN (V.) } \\
\quad(n=6)\end{array}$ \\
\hline $\begin{array}{l}\text { Kreatinin } \\
\text { (umol/1) } \\
\text { középérték } \\
\text { (tartomány) }\end{array}$ & $\begin{array}{c}95 \\
{[49-636]}\end{array}$ & $\begin{array}{c}90 \\
{[70-177]}\end{array}$ & $\begin{array}{c}127 \\
{[49-636]}\end{array}$ & $\begin{array}{c}69 \\
{[61-249]}\end{array}$ \\
\hline $\begin{array}{l}\text { eGFR } \\
(\mathrm{ml} / \mathrm{min}) \\
\text { középérték } \\
\text { (tartomány) }\end{array}$ & $\begin{array}{c}68 \\
{[7-120]}\end{array}$ & $\begin{array}{c}67 \\
{[35-110]}\end{array}$ & $\begin{array}{c}55 \\
{[7-120]}\end{array}$ & $\begin{array}{c}95 \\
{[23-120]}\end{array}$ \\
\hline $\begin{array}{l}\text { Proteinuria } \\
\text { (mg/nap) } \\
\text { középérték } \\
\text { (tartomány) }\end{array}$ & $\begin{array}{c}2800 \\
{[23-16812]}\end{array}$ & $\begin{array}{c}1000 \\
{[142-2800]}\end{array}$ & $\begin{array}{c}3237 \\
{[260-16812]}\end{array}$ & $\begin{array}{c}4337 \\
{[1145-9787]}\end{array}$ \\
\hline $\begin{array}{l}\text { Albumin } \\
(\mathrm{g} / \mathrm{l}) \\
\text { átlag } \pm \mathrm{SD}\end{array}$ & $31 \pm 8$ & $38 \pm 8$ & $29 \pm 7$ & $28 \pm 9$ \\
\hline $\begin{array}{l}\mathrm{Hgb}(\mathrm{g} \%) \\
\text { átlag } \pm \mathrm{SD}\end{array}$ & $11,0 \pm 2$ & $11,2 \pm 3$ & $10,9 \pm 2$ & $11,1 \pm 2$ \\
\hline $\begin{array}{l}\text { Szisztolés } \\
\text { RR } \\
(\mathrm{Hgmm}) \\
\text { átlag } \pm \text { SD }\end{array}$ & $142 \pm 26$ & $129 \pm 17$ & $145 \pm 27$ & $137 \pm 24$ \\
\hline $\begin{array}{l}\text { Diasztolés } \\
\mathrm{RR} \\
(\mathrm{Hgmm}) \\
\text { átlag } \pm \mathrm{SD}\end{array}$ & $86 \pm 12$ & $80 \pm 8$ & $88 \pm 13$ & $83 \pm 9$ \\
\hline $\begin{array}{l}\mathrm{C} 3(\mathrm{~g} / \mathrm{l}) \\
\text { átlag } \pm \mathrm{SD}\end{array}$ & $0,68 \pm 0,3$ & $1,0 \pm 0,4$ & $0,61 \pm 0,3$ & $0,78 \pm 0,25$ \\
\hline $\begin{array}{l}\mathrm{C} 4(\mathrm{~g} / \mathrm{l}) \\
\text { átlag } \pm \mathrm{SD}\end{array}$ & $0,12 \pm 0,2$ & $0,18 \pm 0,16$ & $0,12 \pm 0,01$ & $0,11 \pm 0,07$ \\
\hline $\begin{array}{l}\text { anti-dsDNS } \\
(\mathrm{U} / \mathrm{ml})^{* *} \\
\text { középérték } \\
\text { (tartomány) }\end{array}$ & $\begin{array}{c}29 \\
{[0-182]}\end{array}$ & $\begin{array}{c}25 \\
{[9-182]}\end{array}$ & $\begin{array}{c}33 \\
{[2-100]}\end{array}$ & $\begin{array}{c}10 \\
{[1-22]}\end{array}$ \\
\hline $\begin{array}{l}\text { SLEDAI- } \\
\text { pontszám }^{* * *} \\
\text { átlag } \pm \text { SD }\end{array}$ & $19,0 \pm 6$ & $17,9 \pm 7$ & $19,9 \pm 6$ & $17,2 \pm 6$ \\
\hline
\end{tabular}

* 5 betegnél nem végeztünk vesebiopsziát, az ő eredményeik csak az „Összes beteg” oszlopban szerepelnek

**Normálérték 0-6 U/ml

*** Normálérték 0

anti-dsDNS = kettős szálú DNS elleni antitest; eGFR = becsült glomerulusfiltrációs ráta; $\mathrm{Hgb}=$ hemoglobin; $\mathrm{LN}=$ lupus nephritis; $\mathrm{RR}=$ vérnyomás; $\mathrm{SD}$ = standard deviáció; SLEDAI = a szisztémás lupus erythematosus betegség aktivitási indexe

adtunk, majd ezt per os napi $1 \mathrm{mg} /$ tskg adaggal folytattuk. Az enyhébb esetekben elegendőnek találtuk a per os szteroidadagolást, amit a legtöbbször $1 \mathrm{mg} /$ tskg adagban indítottunk, majd havonta fokozatosan csökkentve 5-6 hónap alatt értük el a fenntartó, napi 4 mg-ot. Minden beteg kombinált immunszuppresszióban részesült; a kortikoszteroidot 60 betegnél $(82 \%)$ havonta alkalma- 
zott iv. bolus ciklofoszfamiddal egészítettük ki, testsúlytól és állapottól függően 600-1000mg kezdő dózisban, amit a hatástól és az esetleges mellékhatástól függően havi 400-800 mg-mal folytattunk (átlag $633 \pm 108 \mathrm{mg}$, $10,4 \pm 2 \mathrm{mg} / \mathrm{tskg}$ ), és a hólyagkárosodás prevenciója érdekében minden esetben mesznavédelemben adtuk. Protokollunk szerint ezt 6 alkalommal ismételtük, ettől csak kivételes esetekben tértünk el. A 18, klinikailag legsúlyosabb, gyors progressziójú, szövettanilag gyakran félholdas LN-es betegnél plazmaferézis-kezelést is végeztünk, naponta vagy másnaponta, összesen 5 alkalommal. A betegek 15\%-ában, enyhébb manifesztáció alapján, a szteroidot azatioprinnal kombináltuk; két, LN II. osztályú beteg szteroid-monoterápiát kapott.

A fenntartó terápia alacsony dózisú kortikoszteroidot tartalmazott - naponta vagy másnaponta $4 \mathrm{mg}$ metilprednizolont -, amelyet 55\%-ban azatioprinnal egészítettünk ki. A szteroid mellé 9 beteg (12\%) mikofenolátmofetilt kapott, 23 esetben (32\%) ciklosporint tartalmazott a fenntartó immunszuppresszió. A betegek nagyobb hányada a betegség hosszas lefolyása, relabáló jellege miatt az évek során váltakozva többféle ISU-terápiában is részesült. Súlyos relapsus kialakulásakor az indukciós immunszuppressziót ismételtük, azaz szteroidot és ciklofoszfamidot adtunk, enyhébb relapsusnál, továbbá magas ciklofoszfamid kumulatív dózis esetén szteroid és ciklosporin, illetve mikofenolát alkalmazásával. A ciklosporint a gyógyszer szérumszintjének meghatározása alapján dozíroztuk.

Terápiánk mellett 50 betegnél sikerült komplett, 21 esetben részleges remissziót elérni, azonban 28 betegnél egy vagy több alkalommal major relapsus jelentkezett, ami az indukciós immunszuppresszió ismétlését tette szükségessé. A megfigyelési időszak végén dokumentált laboratóriumi ereményeket a 4. táblázat tartalmazza. Az 5 , vesepótló kezelést igénylő beteg kivételével (ld. alább) a szérumkreatinin- és eGFR-értékek a hosszú megfigyelési időszak ellenére sem a proliferatív, sem a membranosus LN csoportjában nem romlottak. Jelentősen mérséklődött a proteinuria, normalizálódott a szérumalbumin, a vérnyomás, a vérkép, a SLEDAI-pontszám, és a legtöbb beteg immunleletei is a normáltartományba kerültek. A LN II. osztályú betegek közül 2 fónél relapsus kapcsán súlyos komplikáció jelentkezett, melynek során jelentős vesefunkció-romlás következett be, dialíziskezelés azonban nem vált szükségessé.

Krónikus dialízis-programba 5 beteg került. Közülük ketten már a diagnózis idején HD-t igényeltek, esetükben a veseelégtelenség végstádiumúnak bizonyult. Egy betegünknél terápiarefrakter, végstádiumú veseelégtelenségig progrediáló diffúz proliferatív LN-szel szembesültünk. Ez a fiatal nőbeteg a gondozásba kerülésekor és a relapsusok kapcsán is a fenti terápiás sémákat kapta. Részleges remissziót el tudtunk ugyan érni, ám kezelésének 12 éve alatt több, egymást követő relapsus lépett fel, melyek kapcsán ismételt szteroidlökéseket, ciklofoszfamidot, ciklosporint, mikofenolátot, később 4 alkalom-
4. táblázat Laboratóriumi és klinikai adatok a gondozási időszak (119 hónap [3-264]) végén, a szövettani eredmények alapján csoportosítva

\begin{tabular}{|c|c|c|c|c|}
\hline & $\begin{array}{l}\text { Összes } \\
\text { beteg* }^{*} \\
(\mathrm{n}=73)\end{array}$ & $\begin{array}{l}\text { LN II. } \\
(\mathrm{n}=7)\end{array}$ & $\begin{array}{c}\text { Proliferatív } \\
\text { LN } \\
(\text { III. + IV. + } \\
\text { V. + III. }) \\
(\mathrm{n}=55)^{\star * \star \star}\end{array}$ & $\begin{array}{c}\text { Membrano- } \\
\text { sus } \mathrm{LN}(\mathrm{V} .) \\
\quad(\mathrm{n}=6)\end{array}$ \\
\hline $\begin{array}{l}\text { Kreatinin } \\
(\mu \text { mol/1) } \\
\text { középérték } \\
\text { (tartomány) }\end{array}$ & $\begin{array}{c}101 \\
{[55-758]}\end{array}$ & $\begin{array}{c}122 \\
{[78-281]}\end{array}$ & $\begin{array}{c}105 \\
{[55-758]}\end{array}$ & $\begin{array}{c}68 \\
{[56-216]}\end{array}$ \\
\hline $\begin{array}{l}\text { eGFR } \\
\text { (ml/min) } \\
\text { középérték } \\
\text { (tartomány) }\end{array}$ & $\begin{array}{c}63 \\
{[10-120]}\end{array}$ & $\begin{array}{c}38 \\
{[18-110]}\end{array}$ & $\begin{array}{c}60 \\
{[10-120]}\end{array}$ & $\begin{array}{c}115 \\
{[24-120]}\end{array}$ \\
\hline $\begin{array}{l}\text { Proteinuria } \\
\text { (mg/nap) }\end{array}$ & $\begin{array}{c}273 \\
{[0-4452]}\end{array}$ & $\begin{array}{c}275 \\
{[80-2596]}\end{array}$ & $\begin{array}{c}370 \\
{[0-4452]}\end{array}$ & $\begin{array}{c}204 \\
{[55-1640]}\end{array}$ \\
\hline
\end{tabular}

középérték

(tartomány)

\begin{tabular}{|c|c|c|c|c|}
\hline $\begin{array}{l}\text { Albumin }(g / 1) \\
\text { átlag } \pm S D\end{array}$ & $40 \pm 5$ & $36 \pm 6$ & $40 \pm 5$ & $45 \pm 7$ \\
\hline $\begin{array}{l}\mathrm{Hgb}(\mathrm{g} \%) \\
\text { átlag } \pm \mathrm{SD}\end{array}$ & $12,6 \pm 2$ & $11,7 \pm 2$ & $12,6 \pm 2$ & $12,5 \pm 1,6$ \\
\hline $\begin{array}{l}\text { Szisztolés RR } \\
(\mathrm{Hgmm}) \\
\text { átlag } \pm \text { SD }\end{array}$ & $123 \pm 13$ & $116 \pm 18$ & $124 \pm 13$ & $122 \pm 13$ \\
\hline $\begin{array}{l}\text { Diasztolés RR } \\
(\text { Hgmm }) \\
\text { átlag } \pm \text { SD }\end{array}$ & $78 \pm 8$ & $72 \pm 7$ & $79 \pm 8$ & $76 \pm 10$ \\
\hline $\begin{array}{l}\mathrm{C} 3(\mathrm{~g} / \mathrm{l}) \\
\text { átlag } \pm \mathrm{SD}\end{array}$ & $1,1 \pm 0,3$ & $1,1 \pm 0,4$ & $1,09 \pm 0,3$ & $1,19 \pm 0,27$ \\
\hline $\begin{array}{l}\mathrm{C} 4(\mathrm{~g} / \mathrm{l}) \\
\text { átlag } \pm \mathrm{SD}\end{array}$ & $0,23 \pm 0,14$ & $0,28 \pm 0,16$ & $0,24 \pm 0,1$ & $0,13 \pm 0,09$ \\
\hline $\begin{array}{l}\text { anti-dsDNS } \\
(\mathrm{U} / \mathrm{ml})^{* *} \\
\text { középérték } \\
\text { (tartomány) }\end{array}$ & $\begin{array}{c}5 \\
{[0-100]}\end{array}$ & $\begin{array}{c}10 \\
{[0-100]}\end{array}$ & $\begin{array}{c}5 \\
{[1-96]}\end{array}$ & $\begin{array}{c}5 \\
{[2-33]}\end{array}$ \\
\hline $\begin{array}{l}\text { SLEDAI- } \\
\text { pontszám }^{* * *} \\
\text { átlag } \pm \text { SD }\end{array}$ & $2,9 \pm 4$ & $1,1 \pm 2$ & $3,2 \pm 5$ & $2,2 \pm 2$ \\
\hline
\end{tabular}

* 5 betegnél nem végeztünk vesebiopsziát, az ő eredményeik csak az „Összes beteg” oszlopban szerepelnek

**Normálérték 0-6 U/ml

$\star * *$ Normálérték 0

****A krónikusdialízis-programba került betegek kreatinin- és eGFRértékeit nem értékeltük

anti-dsDNS = kettős szálú DNS elleni antitest; eGFR = becsült glomerulusfiltrációs ráta; $\mathrm{Hgb}=$ hemoglobin; $\mathrm{LN}=$ lupus nephritis; $\mathrm{RR}=$ vérnyomás; $\mathrm{SD}=$ standard deviáció; SLEDAI = a szisztémás lupus erythematosus betegség aktivitási indexe

mal rituximabot adtunk, plazmacserét is végeztünk. A folyamatosan fenntartott kombinált immunszuppresszió ellenére remisszió csak átmenetileg volt elérhető; a legtöbbször extrém magas anti-dsDNS-szint ebben az időszakban nem normalizálódott, a komplementek a normálisnál mindig alacsonyabbak voltak. Vesefunkciója fokozatosan romlott, és 12 év után dialízist kellett indítani, 
mely mellett klinikai állapota teljes mértékben rendeződött, az immunaktivitás megszúnt. Napjainkban a fiatal nőbeteg édesanyjával élődonoros vesetranszplantációra készül. További 2 fiatal nőbetegünk krónikus veseelégtelensége terhességük kapcsán progrediált a végstádiumig. Mindkét fiatal nő a graviditást megelőzően is beszúkuült vesefunkcióval rendelkezett, ám a fokozott rizikó ellenére ragaszkodtak a terhesség kiviseléséhez. A szülést követően egyiküknél dialízist kellett indítani, később vesetranszplantálták, a másikuk preemptív élődonoros vesetranszplantációban részesült. Sikeres második vesetranszplantációban részesült az a beteg is, aki a gondozásunkba kerülésekor már tartósan HD-re szorult. A graftja évek óta jól funkcionál, SLE-immunaktivitás nincs.

Szerológiai antifoszfolipid/antikardiolipin pozitivitás 25 betegnél, ANCA-pozitivitás 18 betegnél volt kimutatható, azonban klinikai tünetekkel járó antifoszfolipidszindrómát csak 10 , vasculitisre utaló tüneteket mindössze 5 betegnél találtunk. A SLE ezen komplikációi az alapbetegségnek a fentiekben bemutatott ISU-kezelésével rendeződtek.

A megfigyelési időszak során 7 beteg exitált, további 2 beteg sorsa ismeretlen. A hét exitus hátterében 3 esetben cardiovascularis esemény, 3 esetben infekció, l betegnél uteruscarcinoma állt. A szövődmények a legnagyobb számban infekciók voltak; súlyos fertőzés 26 betegnél (36\%) jelentkezett, osteoporosis 18 fónél (25\%) került megállapításra, iatrogén leukopenia 9 fơnél (12\%), szteroiddiabetes 6 betegben ( $8 \%$ ) alakult ki. Vénás thrombosist 16 esetben $(22 \%)$ diagnosztizáltunk, amelyeket sikeresen gyógyítottuk.

\section{Megbeszélés}

Retrospektív obszervációs vizsgálatunk alapján a LN széles spektrumú veseérintettséggel járó, de az esetek döntó hányadában megfelelően kezelhető betegségnek bizonyult. Betegeink sokszor előrehaladott stádiumban kerültek gondozásunkba, ami jelentősen befolyásolja a hosszú távú kimenetelt. A vesebiopszia az esetek 75\%ában a legsúlyosabb, proliferatív LN-t igazolt. A vesefunkció a diagnózis felállításakor a legtöbb betegben beszúkült volt, 12 beteg dialízisre szorult, és számos esetben a proteinuria is nephroticus mértéket ért el. Terápiánk mellett az akutan kialakult súlyos veseelégtelenség minden betegnél szanálódott, és a dialízis elhagyhatóvá vált. A hosszú távú, átlagosan csaknem 10 éves követés alatt sikerült biztosítanunk a vesemúködés stabilizálódását, az egyéb klinikai és immuneredmények rendeződését. Kiemelt figyelmet érdemelnek a nephrosissal járó membranosus LN-es esetek is, amelyeknél a súlyos proteinuria okozta rizikótényezők és a késői vesekárosodás kivédésére szintén indokolt a kombinált immunszuppresszió. Tapasztalataink alapján szövődmények fenyegetik az enyhébbnek tartott, II. osztályú $\mathrm{LN}$-es betegeket is, aminek magyarázata a legtöbbször élethossziglan fennálló szisztémás betegség komplikációi és a szükségszerú immunszuppresszió toxicitása is.

A szakirodalmi ajánlásokkal összhangban eredményeink is alátámasztják, hogy a proteinuria, haematuria, eGFR-csökkenés által valószínúsített LN osztályozása nem határozható meg vesebiopszia elvégzése nélkül, azaz a LN a rutinlabor- és immunleletek alapján nem klasszifikálható [3,7]. A szövettani osztályozás meghatározása nélkülözhetetlen a helyes terápia megválasztásához és a prognózis meghatározásához. A proliferatív és nephroticus proteinuriával járó membranosus LN kezeléséhez kombinált immunszuppresszió szükséges [3, 4, 11-13], ennek alapeleme a kortikoszteroid, amelyet súlyos kórkép esetén iv. lökéskezelés formájában kell alkalmazni, majd per os, fokozatosan csökkentett dózisban adagolni. Szervkárosodás közvetlen veszélyével nem fenyegető esetekben a szteroidot elegendő per os, $1 \mathrm{mg} /$ tskg kezdő dózisban adni, amelyet szintén fokozatosan redukálni kell, 4-6 hónap alatt elérve a fenntartó napi vagy másnapi 4 mg-ot.

Az indukciós ISU-készítmények kombinációjának első vonalbeli képviselője napjainkban is a ciklofoszfamid, melyet súlyos esetben 6 hónapon keresztül havi bolusinfúzió formájában javasolt alkalmazni. Kevésbé súlyos klinikummal járó LN-ben a ciklofoszfamid adható az EuroLupus protokollja szerint, ami alacsonyabb, fix dózisú, azaz $500 \mathrm{mg}$-os bolusokat jelent kéthetente, összesen 6 alkalommal [6]. Indukciós ISU-terápiára alkalmas a mikofenolát is [14-16], ez utóbbi azonban hazánkban LN esetén csak 'off-label' (indikáción túli) alkalmazásban adható. Az OGYÉI-jóváhagyás és NEAK egyedi finanszírozási támogatás elnyerése időigényes, ezért a szer elsősorban fenntartó terápiaként jön szóba. A mikofenolátot külföldi tanulmányok a ciklofoszfamiddal azonos hatékonyságúnak véleményezik, ugyanakkor mellékhatásprofilja előnyösebb, elsősorban a fertilitás megóvása szempontjából [17]. Mindezek alapján célszerú volna hazai gyógyszerészeti befogadása és a megfelelő finanszírozási támogatás elnyerése. A membranosus LN nephrosissal járó formájában is kombinált ISU-terápia szükséges, választhatók a fenti protokollok, de adható a szteroid mellé ciklosporin is [18, 19].

A refrakter LN a szakirodalmi adatok alapján is ritka [20]. Amennyiben a kórkép nem reagál szteroid- és ciklofoszfamidkezelésre, célszerú a szteroidot mikofenoláttal kombinálni. Második vonalbeli terápiaként szóba jön a ciklosporin is. Ezek eredménytelensége esetén rituximabkezelés kísérelhető meg [21-23]. Bár ez a szer LNben kevésbé hatékony a más szisztémás immunbetegségekben elérhető eredményekhez képest, Weidenbusch és $m$ tsai vizsgálatában rituximab alkalmazásával a „klasszikus" terápiára rezisztens $\mathrm{LN}$-es esetek mintegy kétharmadában sikerült komplett vagy részleges remissziót elérni [9].

A legtöbb, LN miatt indukciós immunszuppresszióban részesített beteg kezelését a remisszió elérését követően fenntartó immunszuppresszióval kell folytatni, 
amely a legtöbbször alacsony dózisú szteroid és azatioprin kombinációjával biztosítható [8]. Ez utóbbi szer helyett saját tapasztalataink alapján is kiváló választás a mikofenolát, illetve alternatívaként ciklosporin is adható [19, 24, 25].

A SLE kezelésének legmodernebb irányelveit az EULAR (European League Against Rheumatism) 2019ben publikált közleménye foglalja össze [26]. Az irányelv egyik újdonsága annak hangsúlyozása, hogy minden SLE-beteg számára javasolt adjuváns terápiaként hidroxiklorokint alkalmazni, amennyiben a szernek nincs ellenjavallata. A hidroxiklorokin hatékonyságát számos nemzetközi tapasztalat támasztja alá; javallata mellett hazai szerzők is állást foglaltak, mivel az több tanulmány eredménye alapján elősegíti a LN remisszióját, csökkenti a relapsusok gyakoriságát és a végstádiumú veseelégtelenség kialakulását [27]. Mindezek alapján magunk is javasoljuk a hidroxiklorokin alkalmazását LN-ben, bár saját beteganyagunkban csak 19 beteg kezeléséhez adtunk adjuváns terápiaként antimaláriás szert (elsősorban klorokint), így tapasztalataink limitáltak. Ennek oka, hogy betegeink legtöbbjénél a LN jóval az antimaláriás készítmény hatékonyságának igazolása előtt került felismerésre és kezelésre.

Az EULAR felhívja a figyelmet arra is, hogy gondosan mérlegelni kell egy-egy ISU-készítmény terápiás hatékonyságát és toxicitását. Ennek gyakorlati jelentősége a súlyos és kevésbé súlyos LN elkülönítése és az utóbbi esetében a ciklofoszfamid dózisának és kezelési időtartamának limitálása, az Euro-Lupus protokollja ajánlásának megfelelően. A proliferatív LN EULAR által 2019-ben javasolt, hazánkban is használatos terápiás algoritmusát az 1. ábrán foglaltuk össze. További szakmai érdekesség az utóbbi évek ázsiai populációban sikeres terápiás próbálkozása, a „multitarget” terápia, melyben a mikofenolátot takrolimusszal kombinálták. Terápiarefrakter, nephrosissal járó esetek kezelésében megkísérelhető a ciklosporin mikofenoláttal történő együttes alkalmazása is [26].

Az általunk gondozott betegek kezelésében, mivel a legtöbb beteg jelentős mértékű proteinuriával, haematuriával került hozzánk, és sok esetben az eGFR beszúkült vesefunkciót igazolt, a kortikoszeroid mellé a legtöbbször a nagy dózisú havi bolus ciklofoszfamidot tartalmazó terápiát alkalmaztuk. A fenntartó immunszuppressziót alacsony dózisú szteroiddal és többnyire azatioprinnal folytattuk (az utóbbit napi 50-75 mg dózisban adagolva). Az azatioprin ineffektivitása vagy mellékhatások jelentkezése esetén kérvényeztük betegeink számára a mikofenolátot, vagy ciklosporint adtunk.

Bár a szteroid hosszú távú alkalmazása számos potenciális mellékhatás kialakulásával járhat, saját tapasztalataink alapján alacsony dózisú fenntartó metilprednizolon a legtöbb betegnél nélkülözhetetlen, teljes elhagyása csak kivételes esetekben válik lehetővé (saját betegeink közül

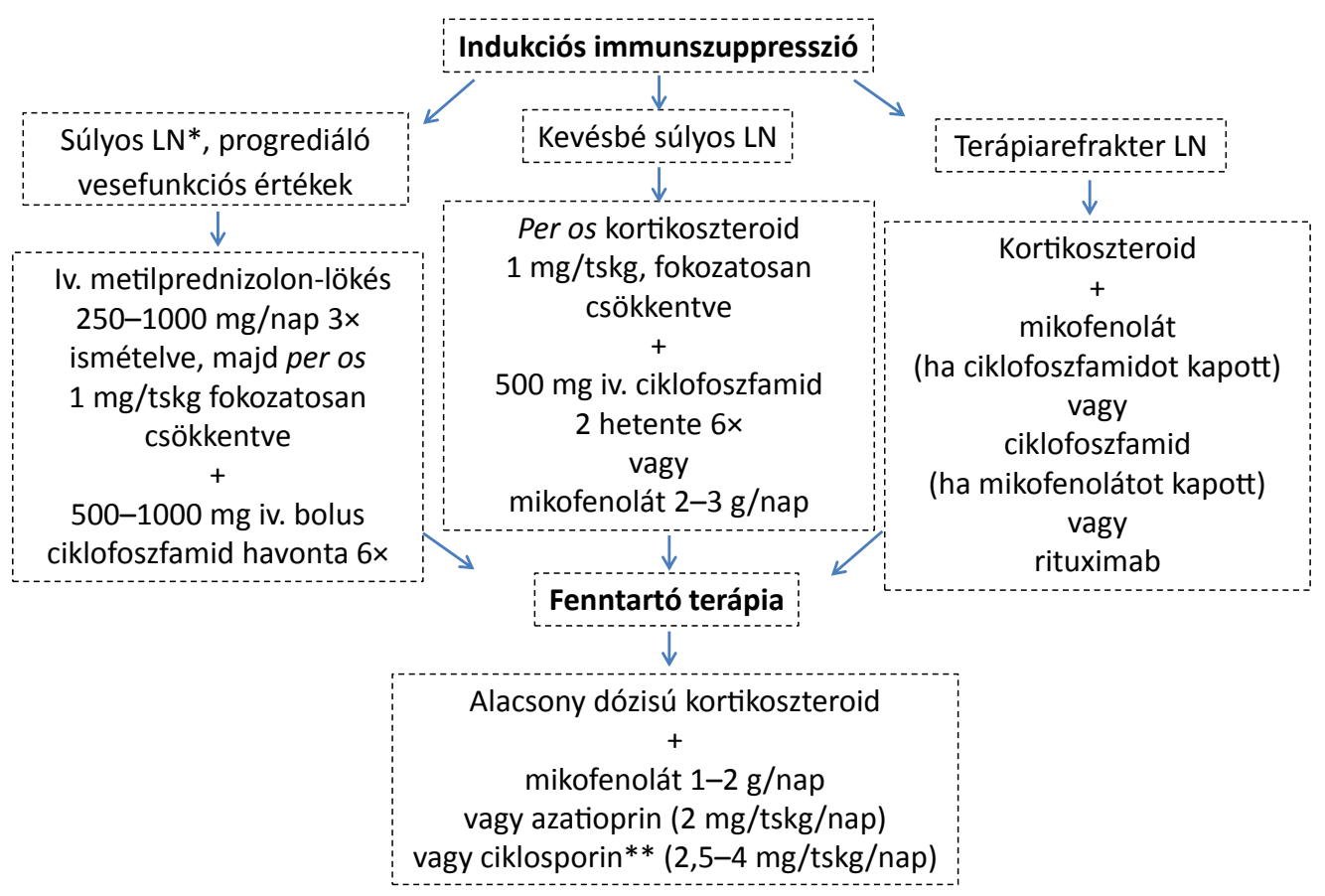

*Csökkenő eGFR, progresszív veseelégtelenség rizikója, félholdképződés a vesebiopsziás mintában **Elsősorban nephroticus proteinuria, illetve mikofenolát-, azatioprinin-tolerancia esetén javasolt A fentiek mellé hidroxiklorokin javasolt, amennyiben nincs ellenjavallata 
mindössze 4 esetben lehetett a szteroidot tartósan mellőzni).

A szakirodalmi adatok és saját tapasztalatunk is azt mutatja, hogy a rendelkezésre álló ISU-szerek kellően hatékonyak a remisszió biztosításához [4, 27-29]. Rendkívül fontos a terápiahűség, azaz a beteg számára előírt szerek pontos szedése. Fiatal nőknél gyakran ütközik nehézségbe a potenciálisan toxikus szerek szükségességének beteg általi elfogadtatása. Vitathatatlan, hogy maga az ISU-terápia is számos szövődmény forrása lehet. Ugyanakkor elégtelen fenntartó terápia vagy az elöírt gyógyszerek szedésének elhagyása a vesefunkciót tovább rontó relapsusok kialakulásához vezethet. Azt is fontos szem előtt tartani, hogy a súlyos LN remissziója megfelelő ISU-terápia alkalmazása esetén is több hónapot vesz igénybe, azaz 4-6 hónapig nem célszerü a hatékonynak tartott készítmény lecserélése. Türelemre van szükség annak biztosítására, hogy a beteg elfogadja a hosszas kezelés indokoltságát. Ezt segíti elő a rendszeres ellenőrzés, a megfelelő orvos-beteg kapcsolat kiépítése, melynek során az ISU-kezelés mellett lényeges a komplex vesevédő terápia alkalmazása is.

\section{Következtetés}

Megállapíthatjuk, hogy a SLE miatt gondozott betegeknél a kóros vizelet és vesefunkciós eredmények nyomon követése kiemelt figyelmet igényel, mivel a beteg sorsának alakulását hosszú távon a LN korai felismerése és megfelelő kezelése határozza meg. LN kialakulásakor nephrologus bevonása a beteg további kezelésébe és gondozásába nélkülözhetetlen. A kórkép nagy dózisú, kombinált ISU-terápiát igényel, a remisszió elérését követően pedig elhúzódóan alkalmazott fenntartó immunszuppresszió szükséges. A rendszeres beteggondozás alapvető jelentőségű a veseelégtelenség progreszsziójának megelőzésére, a végstádiumú veseelégtelenség kialakulásának elkerülésére és az esetleges relapsusok idejében történő felismerésére. A beteggondozást a legcélszerübben olyan team végezze, mely a nephrologus és az immunológus közös tevékenysége mellett magában foglalja mindazon szakembereket - reumatológust, neurológust, szemészt, bőrgyógyászt -, akik hozzájárulhatnak e komplex ellátást igénylő betegcsoport életkilátásának és életminőségének javításához.

Anyagi támogatás: A közlemény megírása és a kapcsolódó kutatómunka anyagi támogatásban nem részesültt.

Szerzői munkamegosztás: P. K. és H. Á. végezte a retrospektív adatgyüjtést és készítette el a kézirat első változatát. A. J., B. H. és K. I. véglegesítették a kézirat jelenlegi formáját. A cikk végleges változatát valamennyi szerző elolvasta és jóváhagyta.

Érdekeltségek: A szerzőknek nincsenek érdekeltségeik.

\section{Köszönetnyilvánítás}

Köszönetünket fejezzük ki minden munkatársunknak, akik hozzájárultak a vizsgálatban szereplő betegek ellátásához. A Szent Margit Kórház Nephrologiai Osztályán 1997 és 2019 között dolgozó szakorvosok és rezidensek osztályos ellátás keretében vettek részt a betegek kezelésében. A szövettani értékelést 2016-tól $d r$. Kardos Magdolna és dr. Fintha Attila (Semmelweis Egyetem, I. Patológiai Intézet) végezte, a laboratóriumi vizsgálatokat a Szent Margit Kórház Központi Laboratóriumának munkatársai, a Honvéd Kórház Immunlaboratóriuma és a SYNLAB Hungary Kft. munkatársai biztosították.

\section{Irodalom}

[1] Rahman A, Isenberg DA. Systemic lupus erythematosus. N Engl J Med. 2008; 358: 929-939.

[2] Hahn BH, McMahon M, Wilkinson A, et al. American College of Rheumatology guidelines for screening, treatment and management of lupus nephritis. Arthritis Care Res (Hoboken). 2012; 64: 797-808

[3] Almaani S, Meara A, Rovin BH. Update on lupus nephritis. Clin J Am Soc Nephrol. 2017; 12: 825-835.

[4] Falk RJ, Dall'Era M, Appel GB. Treatment and prognosis of diffuse or focal proliferative lupus nephritis. UpToDate 2019; www. uptodate.com

[5] Falk RJ, Dall'Era M, Appel GB. Clinical features and therapy of lupus membranous nephropathy. UpToDate 2019; www.uptodate.com

[6] Houssiau FA, Vasconcelos C, D'Cruz D, et al. Immunosuppressive therapy in lupus nephritis. The Euro-Lupus Nephritis Trial, a randomized trial of low-dose versus high-dose intravenous cyclophosphamide. Arthritis Rheum. 2002; 46: 2121-2131.

[7] Bertsias GK, Tektonidou M, Amoura Z, et al. Joint European League Against Rheumatism and European Renal AssociationEuropean Dialysis and Transplant Association (EULAR/ERAEDTA) recommendations for the management of adult and paediatric lupus nephritis. Ann Rheum Dis. 2012; 71: 1771-1782.

[8] Contreras G, Pardo V, Leclercq B, et al. Sequential therapies for proliferative lupus nephritis. N Engl J Med. 2004; 350: 971980.

[9] Weidenbusch M, Römmele C, Schröttle A, et al. Beyond the LUNAR trial. Efficacy of rituximab in refractory lupus nephritis. Nephrol Dial Transplant. 2013; 28: 106-111.

[10] Weening JJ, D'Agati VD, Schwartz MM, et al. The classification of glomerulonephritis in systemic lupus erythematosus revisited. J Am Soc Nephrol. 2004; 15: 241-250. [Correction: J Am Soc Nephrol. 2004; 15: 835-836.]

[11] Flanc RS, Roberts MA, Strippoli GF, et al. Treatment of diffuse proliferative lupus nephritis: a meta-analysis of randomized controlled trials. Am J Kidney Dis. 2004; 43: 197-208.

[12] Palmer SC, Tunnicliffe DJ, Singh-Grewal D, et al. Induction and maintenance immunosuppression treatment of proliferative lupus nephritis: a network meta-analysis of randomized trials. Am J Kidney Dis. 2017; 70: 324-336.

[13] Moroni G, Maccario M, Banfi G, et al. Treatment of membranous lupus nephritis. Am J Kidney Dis. 1998; 31: 681-686.

[14] McCune WJ. Mycophenolate mofetil for lupus nephritis. N Engl J Med. 2005; 353: 2282-2284.

[15] Ginzler EM, Dooley MA, Aranow C, et al. Mycophenolate mofetil or intravenous cyclophosphamide for lupus nephritis. N Engl J Med. 2005; 353: 2219-2228.

[16] Appel GB, Contreras G, Dooley MA, et al. Mycophenolate mofetil versus cyclophosphamide for induction treatment of lupus nephritis. J Am Soc Nephrol. 2009; 20: 1103-1112.

[17] Henderson LK, Masson P, Craig JC, et al. Induction and maintenance treatment of proliferative lupus nephritis: a meta-analysis 
of randomized controlled trials. Am J Kidney Dis. 2013; 61: 74-87.

[18] Austin HA 3rd, Illei GG, Braun MJ, et al. Randomized, controlled trial of prednisone, cyclophosphamide, and cyclosporine in lupus membranous nephropathy. J Am Soc Nephrol. 2009; 20: 901-911.

[19] Zhang X, Ji L, Yang L, et al. The effect of calcineurin inhibitors in the induction and maintenance treatment of lupus nephritis: a systematic review and meta-analysis. Int Urol Nephrol. 2016; 48: 731-743.

[20] Falk RJ, Dall'Era M, Appel GB. Therapy of resistant or relapsing diffuse or focal proliferative lupus nephritis. UpToDate 2019; www.uptodate.com

[21] Rovin BH, Furie R, Latinis K, et al. Efficacy and safety of rituximab in patients with active proliferative lupus nephritis. The Lupus Nephritis Assessment with Rituximab Study. Arthritis Rheum. 2012; 64: 1215-1226.

[22] Chavarot N, Verhelst D, Pardon A, et al. Rituximab alone as induction therapy for membranous lupus nephritis: a multicenter retrospective study. Medicine 2017; 96: e7429.

[23] Jónsdóttir T, Zickert A, Sundelin B, et al. Long-term follow-up in lupus nephritis patients treated with rituximab - clinical and histopathological response. Rheumatology 2013; 52: 847-855.

[24] Tamirou F, D'Cruz D, Sangle S, et al. Long-term follow-up of the MAINTAIN Nephritis Trial, comparing azathioprine and mycophenolate mofetil as maintenance therapy of lupus nephritis. Ann Rheum Dis. 2016; 75: 526-531.
[25] Stoenoiu MS, Aydin S, Tektonidou M, et al. Repeat kidney biop sies fail to detect differences between azathioprine and mycophenolate mofetil maintenance therapy for lupus nephritis: data from the MAINTAIN Nephritis Trial. Nephrol Dial Transplant. 2012; 27: 1924-1930.

[26] Fanouriakis A, Kostopoulou M, Alunno A, et al. 2019 update of the EULAR recommendations for the management of systemic lupus erythematosus. Ann Rheum Dis. 2019; 78: 736-745.

[27] Szabó MZs, Kiss E. Clinical guideline for the treatment of lupus nephritis and a single-centre results of mycofenolate mofetil among patients with lupus nephritis in the National Institute of Rheumatology and Physiotherapy, Budapest. [A lupus nephritis kezelésének irányelvei, valamint a mycofenolat mofetil hatékonyságának bemutatása intézetünk lupus nephritises betegeinek körében.] Orv Hetil. 2016; 157: 1385-1393. [Hungarian]

[28] Wilhelmus S, Bajema IM, Bertsias GK, et al. Lupus nephritis management guidelines compared. Nephrol Dial Transplant. 2016; 31: 904-913.

[29] Chen Y, Sun J, Zou K, et al. Treatment for lupus nephritis: an overview of systematic reviews and meta-analyses. Rheumatol Int. 2017; 37: 1089-1099.

(Haris Ágnes dr., Budapest, Péterfy S. u. 8-20., 1076 e-mail: agnesharis@hotmail.com)

\section{"Ab alio exspectes alteri quod feceris." (Mástól ne várj egyebet, csak mit magad tennél vele.)}

A cikk a Creative Commons Attribution 4.0 International License (https://creativecommons.org/licenses/by/4.0/) feltételei szerint publikált Open Access közlemény, melynek szellemében a cikk bármilyen médiumban szabadon felhasználható, megosztható és újraközölhetö, feltéve, hogy az eredeti szerzỏ és a közlés helye, illetve a CC License linkje és az esetlegesen végrehajtott módosítások feltüntetésre kerülnek. (SID_1) 